\title{
BANJIR DAN UPAYA PENANGANAN PASCA KEMERDEKAAN TAHUN 1955 - 1971 \\ DI TULUNGAGUNG
}

\author{
Latif Kusairi," Martina Safitry, Faridhatun Nikmah
}

latifkusairi3018@gmail.com

\begin{abstract}
ABSTRAK
Penelitian ini bertujuan untuk memaparkan bencana banjir dan upaya penanganan pasca kemerdekaan tahun 1955-1971 di daerah Tulungagung. Metode yang digunakan dalam penelitian ini kualitatif deskriptif dengan mendeskripsikan dalam bentuk kata banjir dan penanganannya pasca kemerdekaan. Adapun tipe yang digunakan dalam penelitian ini deskriptif interpretatif. Tempat yang digunakan dalam penelitian ini adalah daerah Tulungagung. Subjek yang digunakan dalam penelitian ini masyarakat Tulungagung yang tahu dan mengalami banjir pasca kemerdekaan. Sumber data yang digunakan dalam penelitian ini terbagi menjadi dua sumber, yaitu sumber primer dan sekunder. Teknik pengumpulan data yang digunakan dalam penelitian terdiri heuristik, kritik, interpretasi, dan historiografi. Hasil penelitian ini bahwa terjadinya banjir terdiri dari beberapa faktor yang menanggulangi, seperti meluapnya aliran Sungai Brantas, meletusnya Gunung Kelud, iklim cuaca, dan curah hujan yang tinggi, dll. Dalam upaya penanganan banjir dapat dilakukan dengan cara pembuat Terowongan Neyama, pembuatan bendungan, perbaikan terowongan, penampungan pasir di Gunung Kelud, penyempurnakan Parit Raya, pembuatan waduk Kali Ngasinan dan Kali Ngrowo, pembuatan pintu Kali Ngrowo dan Gesikan, perbaikan daerah pengaliran Kali Ngrowo dan Kali Ngasinan, dan meninggikannya tanggul yang berada di Sungai Brantas.
\end{abstract}

\begin{abstract}
This study aims to describe the flood disaster and post-independence handling efforts in 1955-1971 in the Tulungagung area. The method used in this study is descriptive qualitative by describing it in the form of words of flood and its handling after independence. The type used in this research is interpretive descriptive. The place used in this study is the Tulungagung area. The subjects used in this study were the Tulungagung people who knew and experienced postindependence floods. The data sources used in this study are divided into two sources, namely primary and secondary sources. The data collection techniques used in the study consisted of heuristics, criticism, interpretation, and historiography. The results of this study that the occurrence of flooding consists of several factors that cope, such as the overflow of the Brantas River, the eruption of Mount Kelud, the weather climate, and high rainfall, etc. In an effort to deal with flooding, it can be done by making the Neyama Tunnel, making dams, repairing tunnels, sand shelter on Mount Kelud, refining the Parit Raya, making the Ngasinan and Kali Ngrowo reservoirs, making the Ngrowo and Gesikan gates, repairing the Ngrowo and Kali rivers. Ngasinan, and the elevation of embankments on the Brantas River.
\end{abstract}

Keyword: Banjir, Penanganan, Tulungagung, Pasca Kemerdekaan,

\footnotetext{
*Fakultas Adab dan Bahasa, Institut Agama Islam Negeri Surakarta.
} 


\section{PENDAHULUAN}

Dalam sejarah peradaban manusia, terdapat bukti-bukti bahwa pusat peradaban yang paling tua muncul di sepanjang adalah sungai-sungai besar. Dapat diketahui dari peradaban lembah Sungai Nil di Mesir, Eufrat dan Tigris di Mesopotamia, Indus di India, Hoangho dan Yang Tse di Cina. Peradaban ini berkaitan terkait dengan sungai-sungai besar yang ada di sepanjang daerah aliran sungai. Bahkan di tempat inilah pusat kehidupan yang nantinya akan melahirkan sebuah peradaban. Hal ini sesuai dengan yang diungkapkan oleh Toynbe bahwa lingkungan fisik dan lingkungan manusia mewujudkan stimulasi bagi lahirnya suatu peradaban. ${ }^{1}$ Pengelolaan sungai yang kurang baik dapat menyebabkan bencana banjir .

Banjir adalah kejadian alam yang sulit diduga oleh manusia karna datanganya secara tiba-tiba dengan priodisitas yang menentu, kecuali daerah yang sudah menjadi langganan banjir. Banjir merupakan sebuah kondisi di mana aliran air yang jatuh secara tidak maksimal tertampung oleh palung sungai. ${ }^{2}$ Bencana banjir disebabkan adanya beberapa faktor yang mempengaruhi, seperti membuang sampah di sungai, menebang pohon, dampak tersebut akan mengancam eksistensi organisme hidup. ${ }^{3}$ Faktor lain yang ditimbulkan dari banjir adalah iklim dan curah hujan yang tinggi, khususnya daerah dataran rendah ke pegunungan. ${ }^{4}$ Dari uraian di atas merupakan faktor penanggulangan banjir.

Bencana banjir di Indonesia seolah menjadi menu setiap tahun, seperti halnya di DKI Jakarta, banjir bisa dikatakan sebagai menu tiap musim penghujan. Banjir di DKI Jakarta ini diakibatkan adanya saluran Sungai Ciliwung yang tidak mampu menampung air yang ada. Hal tersebut diakibatkan kebiasaan masyarakat yang sering membuang sampah sembarangan sehingga menyebabkan banjir. Badan Penanggulangan Daerah Provinsi (BPDP) DKI Jakarta bahwa daerah yang terkena banjir terdiri dari 18 titik, yakni 4 titik di wilayah Jakarta Selatan dan

\footnotetext{
${ }^{1}$ Daldjoeni, 1984: Geografi Kesejarahan Indonesia I. Bandung: Alumni.hal.99

${ }^{2}$ Daniati, R. P., \& Sariffudin. 2015. Tingkat Kerentanan Masyarakat Terhadap Bencana Banjir di PerumnaasTlagasari Kota Semarang. Jurnal Pengembangan, 3(2).

${ }^{3}$ Sumarkanto. 2002. Pencemaran Lingkungan Perairan Sungai Salah Satu Faktor Penyebab Banjir di Jakarta. Jurnal Teknologi Lingkungan, 3(1), 13.

${ }^{4}$ Yusuf, Y. 2005. Anantomi Banjir Kota Pantai: Perspektif Geografi. Surakarta: Pustaka Cakra.
} 
14 titik di wilayah Jakarta Timur. ${ }^{5}$ Pemerintah Provinsi DKI Jakarta melalui BPDP DKI Jakarta melakukan penanganan dengan melakukan koordinasi dengan kelurahan serta memberikan peringatan kepada masyarakat yang berada di bantaran Sungai Ciliwung melalui SMS Blast saat Bendung Katulampa dan Pintu Air Depok mengalami kenaikan status Siaga 1. BPDP juga berkoordinasi dengan SKPD terkait, seperti Dinas Sumber Daya Air melalui satgas SDA kecamatan untuk melakukan penyedotana air dengan pompa air yang disediakan oleh Dinas Sumber Daya Air. Selain itu, dinas lingkungan juga melakukan adanya pengangkutan sampah akibat banjir. ${ }^{6}$

Banjir juga terjadi di daerah Yogyakarta Jawa Tengah. Daerah yang terkena banjir meliputi tiga kabupaten, yaitu Bantul, Gunumg Kidul, dan Kulon Progo sedangkan di Jawa Tengah (Jateng) mencakup dua provisi, yaitu Kabupaten Wonogiri dan Purworejo. Menurut Sutopo selaku Kapusdatinmas BNPB menjelaskan bahwa BNBP masih melakukan penanganan terhadap bencana banjir Yogyakarta-Jateng. Penanganan tersebut dengan melakukan evakuasi, pencarian korban hilang, dan memberikan bantuan kepada masyarakat ${ }^{7}$.

Berbeda dengan banjir yang terjadi di Tulungagung yang mempunyai alur panjang dari beberapa peristiwa alam. Munculnya letusan Gunung Kelud yang laharnya mengalir ke Sungai Brantas merupakan faktor dominan munculnya banjir di Tulungagung. Kondisi tersebut menyebabkan sedimentasi dasar sungai naik yang menyebabkan air yang harusnya bisa ditampung justru meluap ke daratan. Memang munculnya banjir yang disebabkan letusan Gunung Kelud bukan faktor tunggal, namun juga banyak disebabkan adanya berbagai faktor seperti adanya proses penggundulan hutan dan kurang tertatanya saluran air yang ada.

Pada tahun 2019 terjadi adanya banjir serentak yang melanda daerah Tulungagung, Blitar, dan Trenggalek provinsi Jawa Timur. Banjir tersebut diakibatkan karena hujan deras bercampur dengan luapan sungai yang masuk ke rumah warga, seperti wilayah Dusun Kasrepan, Desa Demuk, Kecamatan Pucanglaban yang ketinggian airnya mencapai $30 \mathrm{~cm} \mathrm{-1} \mathrm{m.} \mathrm{Menurut} \mathrm{Suroto,}$ di Desa Waung banjir sangat parah dengan adanya tanggul sungai yang ambrol sepanjang $5 \mathrm{~m}$.

\footnotetext{
${ }^{5}$ A, Daud, . 2019. BNPB: 477 Bencana Alam Terjadi Sejak Januari 2019. Katadata.Co.Id.

${ }^{6}$ A. Jatmiko. April 2019. Korban Banjir Jakarta, Sebanyak 2.942 Warga Harus Mengungsi. Katadata.Co.Id.

7 Ariefana, P., \& Aranditio, S. 2019. "Banjir Yogyakarta - Jateng, 2 Tewas, 7.240 Orang Mengungsi”. Suara.Com.
} 
Banjir tersebut tidak hanya membanjiri jalan raya dan rumah warga melainkan air sungai yang membawa material lumpur yang merendam area persawahan. ${ }^{8}$ Sementara di Kabupaten Blitar melanda di Desa Jimbe, Kecamatan Kademangan. Berdasarkan keterangan Polres Blitar banjir berasal dari luapan Sungai Sentoyo yang melintasi lima kecamatan di antaranya adalah Desa Suruhwadang, Desa Sumberejo, Desa Dawuhan, Desa Plumpungrejo, dan Desa Jimbe. Ketinggian air mencapai $30 \mathrm{~cm}-1 \mathrm{~m}$. Kondisi serupa juga terjadi di kabupaten Trenggalek. Banjir ini juga melanda beberapa kecamatan di antaranya adalah Kecamatan Trenggalek, Kecamatan Ngantru, Kecamatan Karangan, Kecamatan Suruh, dan Kecamatan Panggul. Ketinggian air di jalan dan rumah warga mencapai $2 \mathrm{~m}$. Selain diakibatkan curah hujan yang tinggi juga diakibatkan karena ketidakmampuan Sungai Ngasinan dalam menampung limpahan air hujan. Di sisi lain, sendimentasi yang terjadi di Sungai Ngasinan tergolong sangat parah. Seharusnya dilakukan dengan upaya pengerupan dasar sungai. Namun, Pemkab mengabaikannya. Paginya rendaman di sejumlah wilayah banjir berangsur surut. Namun, tidak menutup kemungkinan terjadi banjir susulan. Sementara petugas Basarnas Pos SAR Trenggalek bersama polisi dan TNI melakukan evakuasi menggunakan perahu karet dengan memprioritaskan warga lansia, anak-anak, dan perempuan. ${ }^{9}$

Di sisi lain, banjir juga disebabkan adanya siklus panjang tujuh belas tahunan meletusnya Gunung Kelud, seperti yang terjadi peristiwa meletusnya Gunung kelud pada tahun $1884 .^{10}$ Munculnya letusan tersebut mengakibatkan sungai-sungai kecil tidak dapat berfungsi airnya dikarenakan letusan Gunung Kelud. Letusan Gunung Kelud ini menyebabkan daerah sekitar terkena imbasnya, seperti daerah Blitar, Kediri, dan Tulungagung yang berdampak besar. Hal inilah yang mengakibatkan adanya peribahasa yang sering digunakan oleh masyarakat akan dampak yang ada di tiga daerah tersebut, seperti Blitar dadi latar, Kediri dadi kali, Tulungagung dadi kedung. ${ }^{11}$

Topografi daerah Tulungagung berada di dataran rendah dikelilingi oleh pegunungan, bagian selatan merupakan rentetan daerah Pegunungan Kapur Selatan Jawa yang kurang

\footnotetext{
${ }^{8}$ S. Said, 2019. Madiun Dilanda Banjir Hebat, 515 Orang Dievakuasi. Sindonews.Com.

9 S. Arif, 2019. Hujan Deras, Banjir Serentak Landa Tulungagung, Blitar, dan Trenggalek. Sindonews.Com.

10 Arsip Daerah Jawa Timur, no 124/6K/PPB. Kadipaten Ngrowo merupakan wilayah Tulungagung sebelum nantinya pada tahun 1901 berubah menjadi Kabupaten Tulungagung. (n.d.).

${ }^{11}$ Surya, 3 Oktober 2007.
} 
memungkinkan air bisa dibuat melalui daerah tersebut. Karena tidak adanya daerah pematusan inilah menyebabkan terbentuknya rawa-rawa di daerah selatan (Rawa Campudarat). Bukit-bukit kapur dan gunung berapi yang berada disekitarnya, berabad-abad lamanya secara berganti mengisi rawa tersebut, sedangkan proses alamiah lainnya yaitu munculnya Sungai Ngasinan yang bermuara ke rawa menjadikan genangan semakin luas. Bila musim hujan, dapat dipastikan banjir akan mengenangi daerah sekitarnya termasuk wilayah Kadipaten Ngrowo. Topogarfi yang kurang menguntungkan inilah yang menyebabkan sering terjadinya banjir.

Berdasarkan pandangan geografis, sejak zaman kolonial Belanda sampai zaman orde lama wilayah Tulungagung bagian tengah dan selatan merupakan hamparan rawa yang sangat luas dan dalam. ${ }^{12}$ Dalam perjalanan sejarah Tulungagung terjadi banjir sejak zaman Kolonial Belanda sampai sekarang. ${ }^{13}$ Sebagai daerah yang berada di dataran rendah dinamika perekonomian Tulungagung telah banyak didukung dari sektor pertanian. Munculnya banjir yang hampir terjadi tiap tahun telah membawa sebuah implikasi negatif bagi kelancaran pertanian. Daerah ini juga menghasilkan banyak tebu yang memasok dua Pabrik Gula yang dibangun Belanda pada tahun 1800-an. Selain tumbuh kembangnya sektor pertanian juga didukung adanya transportasi yang memadai serta alam yang kurang bagus, sehingga ketika terjadi pengendapan lumpur di Sungai Brantas, Tulungagung yang berada di dataran rendah mendapat imbasnya yaitu banjir ${ }^{14}$

Kemenangan Jepang atas Belanda dalam perang pasifik telah menghantarkannya untuk menguasai Indonesia. Termasuk wilayah Tulungagung yang juga turut dikuasainya, karena faktor ekonomi yang sangat besar dan keadaan pantainya yang sangat strategis maka Jepang berani melakukan penanggulangan terhadap banjir di Tulungagung. Aiko Kurasawa dalam bukunya Mobilitas dan Kontrol: Studi tentang Perubahan Sosial di Pedesaan Jawa 1942-1945 mengatakan bahwa Proyek Reklamasi Tulungagung ini merupakan proyek drainase besar yang dilakukan Jepang ketika di Indonesia. ${ }^{15}$ Berbagai alasan baik yang dilakukan pihak kolonial Belanda, Jepang atau nantinya oleh Pemerintah Indonesia seolah merupakan faktor geografis

${ }^{12}$ Sang, S. 2013. Sejarah Tulungagung. Kompasiana.Com.

${ }^{13}$ www.tulungagung.go.id. Dalam Sejarah Kabupaten Tulungagung. Diakses 03 September 2008.

14 "Tri Candra Aptianto, "Kota dan Kapitalisme Perkebunan: Jember dalam Perubahan Zaman 1900-1970”, dalam Kota Lama Kota Baru (Yogyakarta, Ombak, 2005) hal. 366.

${ }^{15}$ Karasawa, A. 1993. Mobilisasi dan Kontrol: Studi Tentang Perubahan Sosial di Pedesaan Jawa 1942-1945. Jakarta: Grafindo. 
yang menguntungkan dalam kekayaan alamnya, sehingga dilakukan sebuah upaya penanggulangan banjir.

Penelitian yang relevan dengan penelitian ini pernah dilakukan oleh Novi Isteni ${ }^{16}$ yang berjudul Banjir di Tulungagung Tahun 1955 - 1986. Hasil dari penelitian tersebut menunjukkan bahwa faktor utama penyebab banjir adalah letak geografi dan topografi daerah rawan banjir, faktor lain disebabkan oleh letusan Gunung Kelud yang menyebabkan pendangkalan Sungai Brantas dan adanya curah hujan yang tinggi. Penelitian lain juga pernah dilakukan oleh Arief Nugroho yang berjudul Analisis Faktor Lingkungan dalam Kejadian Leptospirosis Kabupaten Tulungagung. Hasil penelitian menunjukkan bahwa adanya sampah terbuka di depan atau belakang rumah berhubungan dengan kejadian leptospirosis dan mempunyai resiko 16,3 kali lebih besar dalam penyebaran leptospirosis. Dari beberapa penelitian di atas di sini peneliti akan mengkaji tentang bencana banjir dan upaya penanganannya pasca kemerdekaan tahun 1955 1971 di Tulungagung. Penelitian ini lebih ditekankan pada bencana banjir dan upaya penanganan. Dalam penelitian ini tempat yang diangkat dalam penelitian adalah daerah Tulungagung karena daerah tersebut adalah daerah dataran rendah yang dikelilingi pegunungan. Selain itu, daerah ini dijadikan sebagai daerah penghasil marmer terbesar. Untuk itu peneliti tertarik untuk meneliti daerah Tulungagung mengenai banjir dan upaya penanganannya. ${ }^{17}$

\section{METODE PENELITIAN}

Metode yang digunakan dalam penelitian ini adalah kualitatif deskriptif. Meleong mendefinisikan bahwa penelitian kualitatif adalah prosedur penelitian yang menghasilkan data deskriptif berupa kata tertulis atau orang dari orang-orang dan perilaku yang dapat diamati. Penelitian ini adalah deskriptif analisis adalah suatu penelitian yang menjelaskan secara fakta masalah dari lingkup atau wilayah tertentu. ${ }^{18}$ Adapun pendekatan yang digunakan dalam penelitian ini adalah deskriptif interpretatif. Pendekatan interpretatif merupakan sebuah sistem sosial yang memaknai perilaku secara detail langsung mengobservasi. Newman mendefinisikan

${ }^{16}$ Novi Isteni, 2018. Banjir di Tulungagung Tahun 1955 - 1986. Jurnal Avatar, 6(2), 36-45

${ }^{17}$ Nugroho, A. 2015. Analisis Faktor Lingkungan dalam Kejadian Leptospirosis di Kabupaten Tulungagung. Jurnal Balaba, 11(2), 73-80.

${ }^{18}$ Meleong, L. J. 2010. Metodologi Penelitian Kualitatif. Bandung: Remaja Rosdakarya. 
bahwa pendekatan interpretatif adalah pendekatan yang dilakukan dengan cara melihat fakta sebagai sesuatu yang unik dan memiliki konteks dan makna yang khusus sebagai esensi dalam memahami makna sosial. ${ }^{19}$ Penelitian ini lebih difokuskan kepada bencana banjir pasca kemerdekaan dan upaya penangananya tahun 1955-1971 di daerah Tulungagung. Tempat yang digunakan dalam penelitian ini adalah kabupaten Tulungagung provinsi Jawa Timur. Subjek yang digunakan dalam penelitian ini adalah warga yang tahu dan mengalami bencana banjir pasca kemerdekaan.

Pengumpulan sumber data yang digunakan dalam penelitian ini terbagi menjadi dua, yaitu sumber data primer dan sekunder. Sumber data primer berupa foto dan arsip sedangkan sumber data sekunder berupa sumber data yang diperoleh dari internet, buku penunjang, hasil penulisan, skripsi, surat kabar dan majalah yang menuliskan kondisi banjir pada masa tersebut. Dalam keilmuan sejarah terdiri dari empat tahap, yaitu heuristik, kritik, interpretasi, dan historiografi. ${ }^{20}$ Teknik analisis data adalah suatu proses dalam mengurutkan data. Teknik analisis data yang digunakan dalam penelitian ini pertama adalah heuristik dengan cara menentukan topik yang akan dikaji. Kedua, kritik sumber baik kritik internal dan eksternal. Ketiga, pengujian data dengan cara mencari hubungan dari fakta yang ditemukan kemudian dianalisis dan ditafsirkan ke dalam sub bagian yang sesuai. Tahap keempat adalah historiografi berupa tafsiran sesuai fakta yang ada yang disajikan dalam bentuk tulisan yang didasari dengan bukti nyata dan kemudian ditarik kesimpulan. Dalam pengujian kredibilitas data peneliti menggunakan triangulasi data. Menurut Sugiyono, triangulasi terbagi menjadi tiga, yaitu triangulasi sumber, pengumpulan data, dan waktu. ${ }^{21}$ Dalam menguji keabsahan data melalui wawancara subjek dengan cara mengajukan pertanyaan yang telah disusun oleh peneliti terkait dengan bencana banjir dan upaya penanganannya pasca kemerdekaan tahun 1955-1971 di daerah Tulungagung.

19 Newman, L. 2000. Social Research Methods Qualitative dan Quantitative. Approaches: Boston: Allyn and Bacon.

${ }^{20}$ Gostlack, L. 1982. Mengerti Sejarah. Jakarta: Universitas Indonesia Press.

21 Sugiyono. 2018. Metode Penelitian Pendidikan: Pendekatan Kualitatif, Pendekatan Kuantitatif, dan $R \& D$. Bandung: Alfabeta. 


\section{HASIL DAN PEMBAHASAN}

Kabupaten Tulungagung merupakan daerah yang berada di Jawa bagian Selatan, terletak $154 \mathrm{~km}$ ke arah Barat Daya dari Kota Surabaya. Awalnya kabupaten ini dijadikan sebagai Karesidenan Kota Kediri. Nama Tulungagung berdasarkan bahasa mempunyai perkataan "Tulung dan agung." Tulung diartikan sebagai sumber air atau umbul sedangkan agung diartikan sebagai besar. Tulungagung adalah Sumber air yang besar atau pertolongan besar. ${ }^{22}$

Daerah Tulungagung sering terjadi adanya bencana banjir. Banjir merupakan persoalan antara manusia dan alam tempat tinggalnya, yang dihubungkan dengan geohistory atau geosejarah. Faktor penyebab banjir di Tulungagung diakibatkan luapnya Sungai Brantas, meletusnya Gunung Kelud, dan iklim cuaca dan curah hujan. Berikut ini akan dipaparkan penanganan banjir pasca kemerdekaan di Tulungagung.

\section{A. Banjir Pasca Pembuatan Terowongan Neyama}

Kekalahan Jepang pada perang Pasifik dari Sekutu menyebabkan adanya pelepasan kekuasaan Jepang dari Indonesia. Kondisi vacuum of power yang menyebabkan Indonesia mengambil inisiatif untuk memerdekakan diri meski mengalami berbagai ketidakstabilan terutama dalam mengelola wilayahnya sendiri. Heijboer mengatakan bahwa adanya ketidakstabilan Negara Indonesia yang baru merdeka rupanya telah berimbas ke Terowongan Neyama menjadi tidak ada perawatan. ${ }^{23}$ Pasca dibangunnya Terowongan Neyama, kondisi Tulungagung bisa dikatakan bebas banjir. Kekalahan dan kepergian Jepang dari Indonesia rupanya menjadi bom waktu banjir di daerah Tulungagung. Agresi Militer Belanda II pada tahun 1949 telah mengakibatkan banyaknya objek bangunan yang dirusak oleh pejuang Indonesia untuk menghambat laju tentara Belanda. Di Tulungagung tercatat sebagai bangunan terbanyak yang dirusak oleh pejuang Indonesia, salah satunya adalah daerah sekitar Terowongan Neyama. Usaha tersebut bertujuan untuk mengelabuhi tentara Belanda agar tidak dapat mendarat di kawasan Pantai Popoh. Namun, usaha yang dilakukan oleh pejuang Indonesia itu pun gagal karena Belanda sudah mendarat ke kawasan Selatan Jawa Timur lebih tepatnya di pantai Pacitan

22 Tim Penulis. 2004. Sejarah dan Babad Tulungagung edisi Revisi. Tulungagung: Pemkab Tulungagung.

${ }_{23}$ Heijboer, P. 1998. Agresi Militer Belanda: Mempertahankan Pending Zamrud Sepanjang Khatulistiwa 1945 - 19449. Jakarta: Grafindo. 
yang kemudian akan menuju ke Trenggalek dan Tulungagung.

Seorang warga Desa Batokan Kecamatan Ngantru mengatakan bahwa usaha untuk merusak daerah di sekitar terowongan bisa terlaksana. Hal inilah yang mengakibatkan debit penyaluran air di terowongan berkurang. Selain itu, para pejuang juga menghancurkan beberapa Jembatan, seperti Jembatan Ngujang, Jembatan Kereta Api Ngujang, Jembatan Batokan, Jembatan Karangrejo, dan Jembatan Lembupeteng. Usaha tersebut bertujuan untuk memperlambat masuknya tentara Belanda ke daerah sekitar, seperti Kediri dan Blitar. ${ }^{24}$

Kekhawatiran penduduk terhadap banjir di daerah Blitar muncul tanggal 16 dan 17 Maret 1952. Banjir tersebut menenggelamkan beberapa desa, seperti daerah Petung Ombo yang dekat dengan Gunung Kelud. Banjir juga menyebabkan bendungan di daerah Garum mengalami kerusakan sehingga menyebabkan ketidakadanya pengendalian pasir Gunung Kelud. ${ }^{25}$ Demikian juga yang terjadi di Kanigoro yang mengakibatkan bendungan rusak. Kekhawatiran tersebut tidak hanya terjadi pada warga Blitar saja melainkan warga Tulungagung juga khawatir atas bencana banjir.

Kekhawatiran terhadap banjir terjadi di daerah Tulungagung pada 16 Desember 1954 menyebabkan Jembatan Ngujang yang baru dibangun bulan Januari terputus. Terputusnya jembatan dikarenakan jembatan tersebut diterjang oleh banjir. Dari banjir ini meski bisa dikatakan besar. Namun kondisi Sungai Brantas masih bisa menampung air banjir tersebut, dan tidak menyebabkan adanya luapan air di daratan Tulungagung karena Sungai Brantas masih bisa menampunng. pada tahun 1955 banjir besar terjadi yang menyebabkan hampir sebagian besar daerah Tulungagung terendam air.

\section{B. Banjir Pada Masa Kemerdekaan Tahun 1955}

Letusan Gunung Kelud mengakibatkan terjadinya banjir besar pada tahun 1952 dan 1954 merupakan pertanda bagi daerah Tulungagung yang dikaitkan dengan daerah banjir. Pada bulan Desember 1954 terjadi hujan besar di daerah aliran Sungai Brantas yang mengakibatkan putusnya jembatan Ngujang. Meskipun banjir terjadi sangat besar tetapi air tersebut cepat surut sehingga tidak banyak korban.

\footnotetext{
${ }^{24}$ Kadit, wawancara 12 Juni 2008

${ }^{25}$ Pewarta Surabaya, 21 Maret 1952
} 
Pada bulan Juni 1955 biasanya daerah Tulungagung, Blitar, dan Kediri terjadi musim kemarau justru malah berubah menjadi musim hujan. Musim hujan berkisar antara 1-3 hari menyebabkan adanya tanda bajir. Daerah yang terkena banjir dimulai dari daerah Tulungagung sampai daerah Nguntru. ${ }^{26}$ Daerah Nguntru airnya meluap sehingga menyebabkan terputusnya jalur antara Tulungagung bagian Utara yang menuju Kediri dengan kota Tulungagung. Hal ini dikarenakan Jembatan Ngunjang yang dijadikan sebagai salah satu akses penghubung jalan putus diterjang banjir pada bulan Desember 1954. Para penyeberang yang mengunakan Perahu Tambangan (penyeberangan di Sungai Brantas) telah menghentikan operasinya akibat air meluap dan sangat deras. Di daerah Karangrejo banyak tanggul Brantas yang putus. Daerah Pakuntjen yang merupakan pertemuan antara Muara Kali Ngrowo dari Neyama dengan Sungai Brantas juga ikut jebol menyusul tidak kuatnya tanggul akibat desakan air yang berasal dari Kali Ngrowo dan Sungai Brantas, tinggi air yang menyerang daerah ini antara 1 - 3 meter. ${ }^{27}$ Menurut laporan Kabupaten Tulungagung untuk menuju ke kota kendaraan roda 4 hanya melewati jembatan kereta api yang berada di sebelah barat Jembatan Ngujang. yang telah putus, untuk mengatasi antrean tersebut disediakan adanya perahu penyeberangan atau yang lebih dikenal perahu tambang. ${ }^{28}$

Memasuki hari kedua banjir di Tulungagung belum juga surut. Banyak masyarakat yang terkena penyakit gondong, buduk, dan kudis akibat air banjir.Suara Masyarakat, 1 Agustus 1955 Para dokter yang ada di desa sempat kewalahan menerima pasien yang datang untuk berobat sedangkan obat yang dimilikinya sudah habis. Pemerintah Provinsi Jawa Timur dan PMI juga memberikan intruksi bahwa akan ada bantuan obat untuk para korban banjir di Tulungagung. Disamping memberi bantuan kepada penduduk, bupati juga menghimbau kepada para pamong desa agar banjir tidak menghambat proses pemilu. Meskipun banyak warga yang mengungsi. Langkah ini juga dilaporkan kepada Gubernur Jawa Timur bersamaan dengan pelaporan adanya banjir yang sedang terjadi di Tulungagung.

\footnotetext{
${ }^{26}$ Harian Umum, 17 Desember 1954

${ }^{27}$ Suara Masyarakat, 21 Juli 1955

${ }^{28}$ Suara Masyarakat, 5 Agustus 1955
} 


\section{Gambar 1}

Banjir yang terjadi di daerah Kota Tulungagung. Nampak gambar partai konstentan Pemilu 1955.

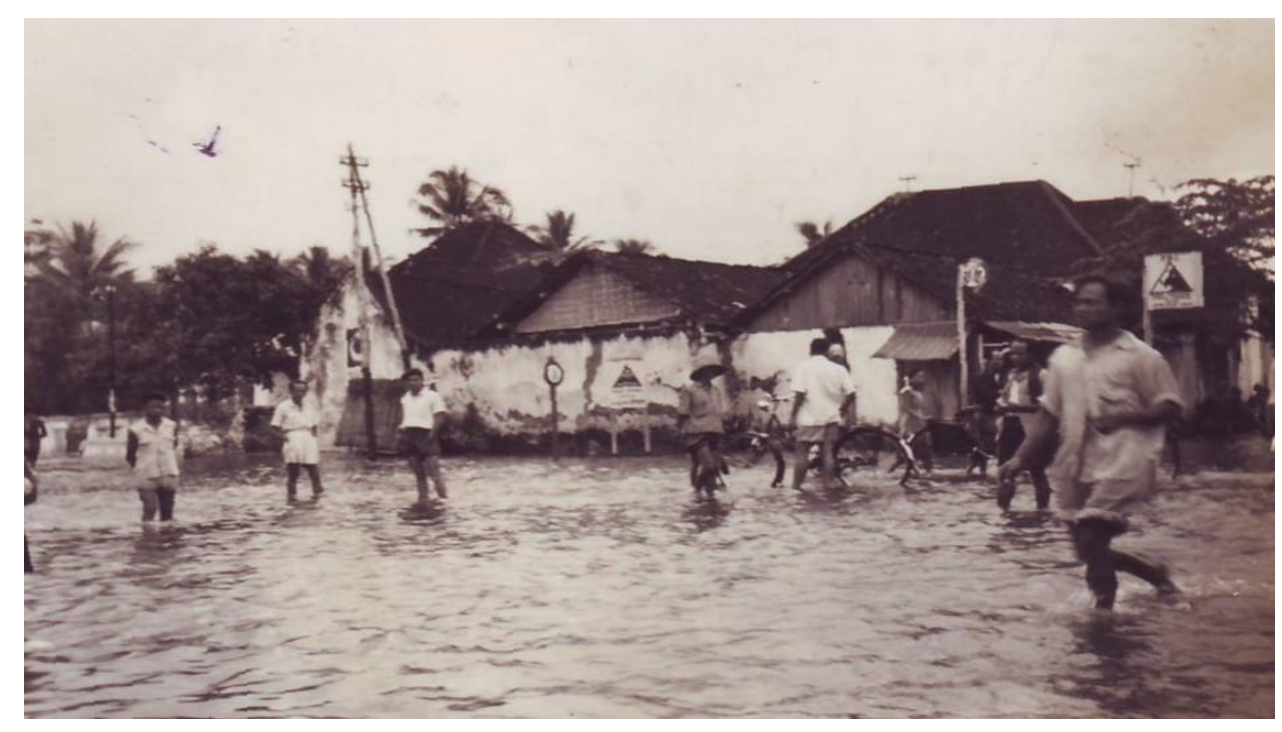

Sumber: Koleksi Arsip Kabupaten Tulungagung

Dari laporan Bupati Tulungagung, Gubernur segera memerintahkan Jawatan Sosial Jawa Timur dan Palang Merah Indonesia wilayah Jawa Timur untuk segera mempersiapkan bantuan berupa keperluan apapun kepada korban banjir.Suara Masyarakat, 1 Agustus 1955 Bagi masyarakat Jawa Timur yang ingin menyumbang diharapkan melalui kedua lembaga tersebut dan tidak perlu langsung ke daerah bencana mengingat transportasi yang sulit dan hanya bisa dilakukan dengan menggunakan Kereta Api.

Akibat banjir yang semakin meningkat, Gubernur Jawa Timur pada tanggal 20 Juli langsung melihat kondisi daerah yang terkena banjir. Dengan susah payah rombongan gubernur bisa meninjau ke Tulungagung. Rombongan diterima langsung oleh Bupati R Moestopo dan instansi jawatannya. Dalam peninjauan Gubernur langsung ke daerah perkotaan yang kondisinya sangat memprihatinkan, kemudian dilanjutkan dengan perjalanan darat menuju daerah timur yaitu di Kecamatan Kalidawir yang sungainya jebol akibat hebatnya banjir. Setelah dari Kalidawir rombongan menuju ke wilayah barat yaitu Kauman tempat mengungsi warga dari wilayah kota. Dalam perjalanan rupanya rombongan terjebak oleh kemacetan warga yang sedang mencari seorang tukang becak yang hanyut terbawa arus banjir. Setelah dari Kalidawir 
rombongan menuju ke wilayah barat, yaitu Kauman tempat mengungsi warga dari wilayah kota. Dalam perjalanan rupanya rombongan terjebak oleh kemacetan warga yang sedang mencari seorang tukang becak yang hanyut terbawa arus banjir.Suara Masyarakat, 26 Juli 1955

Ketiadaan upaya untuk pengentasan banjir secepatnya, menyebabkan pada hujan deras tanggal 24 Juli 1955 yang terus-menerus yang mengakibatkan air mulanya menyusut di Sungai Brantas kembali naik ke daratan. Efek dari hujan itu menyebabkan di Kota Tulungagung semula surut menjadi tergenang sampai 2 meter, sedangkan untuk daerah sekitarnya air lebih tinggi, keadaan lebih parah adalah daerah sekitar Rawa Campurdarat yang memang kondisinya paling rendah. Banjir tanggal 24 Juli ini juga membuat wilayah Kediri yang semula tidak banjir turut ikut banjir. Akibat banjir ini pula tambangan yang digunakan transportasi ke daerah Selatan Brantas atau sebaliknya kembali tidak bisa beroperasi, untuk mencapai Kota Tulungagung satusatunya akses umum hanya menggunakan Kereta Api. ${ }^{29}$ Keadaan yang terjadi akibat banjir ini mengakibatkan orang bersimpati terhadap para korban.

Pihak Jawatan Sosial Jawa Timur dan PMI Jawa Timur membantu sampai menerjunkan relawan banjir. Adanya Himbauan dari bupati terhadap warganya untuk mengungsi, pada kenyataannya banyak yang masih bertahan di rumahnya meski banjir telah mencapai 2 meter, sehingga PMI yang membantu harus berkeliling ke rumah-rumah warga dengan menggunakan perahu untuk sekedar memberikan kebutuhan hidup seperti pakaian, beras, makanan, garam, uang dan bila ada yang sakit juga memberi obat.Suara Masyarakat, 2 Agustus 1955 PMI Cabang Surabaya yang turut serta dalam PMI Jawa Timur ikut membantu dengan memberikan 1000 potong kain dan beberapa uang. ${ }^{30}$ Gubernur Jawa Timur yang baru pulang dari peninjauan banjir juga menggalang dana dengan membuat pos Crisis Center yang gunanya untuk menampung uang dari rasa empati warga masyarakat atas korban banjir.

Dalam menyambut hari Kemerdekaan, bupati menghimbau agar panitia kemerdekaan di tingkat desa, kecamatan, dan kabupaten untuk mengalihkan programnya dari semula yang bersifat lomba, pawai, dan sebagainya supaya dialihkan untuk membantu korban banjir yang bersifat pendidikan, dan pertanian pasca banjir. ${ }^{31}$ Pada tanggal 16 Agustus banjir surut meski

\footnotetext{
${ }^{29}$ Suara Masyarakat, 28 Juli 1955

${ }^{30}$ Suara Masyarakat, 3 Agustus 1955.

${ }^{31}$ Suara Masyarakat, 5 Agustus 1955
} 
masih ada genangan-genangan kecil. Namun, banjir tersebut telah banyak membawa korban baik korban jiwa dan korban material.

Pasca terjadinya banjir besar, Bupati Tulungagung dan Gubernur Jawa Timur melakukan rapat terkait upaya perbaikan di Terowongan Neyama yang dangkal. Hal tersebut diakibatkan karena adanya endapan lumpur dari aliran Kali Ngrowo. Dalam perbaikan Terowongan Neyama ini, gubernur mengatakan bahwa semua itu adalah rencana proyek II sedangkan untuk rencana proyek I adalah membuat bendungan penahan dan penampung pasir lahar Gunung Kelud yang tujuannya untuk memperlambat dangkalnya Sungai Brantas. Setelah adanya kesepakatan itu dimulailah proyek pengerjaan Terowongan Neyama atau lebih disebut menerowong kembali karena terowongan menjadi buntu akibat endapan pasir. Upaya yang dimaksudkan untuk pemeliharaan ini kemudian mengalirkan banjir hingga surut. ${ }^{32}$

Menteri Pekerjaan Umum dan Tenaga, Suroso yang waktu itu melakukan kunjungan ke Jawa Timur menyebutkan bahwa usaha untuk penyempurnaan atas Terowongan Neyama diharapkan bisa menjadi solusi terhadap banjir Tulungagung. Penyempurnaan yang dimaksudkan Suroso bukan usaha yang dilakukan oleh Pemerintah Jawa Timur saat itu yang melakukan penggalian terowongan. Namun usaha ini dimaksudkan untuk memperlebar dan menyempurnakan terowongan. Meskipun dalam kenyataannya Pemerintah Pusat belum bisa menyatakan berapa dana yang akan dikucurkan. Proyek Neyama ini baginya hanya merupakan awal untuk membebaskan Masyarakat Jawa Timur yang berada di sekitar Sungai Brantas terhadap banjir. ${ }^{33}$

Pada tahun 1956 banjir masih saja terjadi meskipun dalam skala kecil karena terowongan bisa beroperasi kembali. Namun, ketidakjelasan ucapan menteri tentang proyek penanganan banjir tersebut telah membawa banjir terus berulang sepanjang tahun. Tidak adanya proyek penanggulangan atas endapan pasir di Sungai Brantas, tanggal 1 Maret 1957 banjir mengamuk daerah di sekitar Sungai Brantas. Banjir terjadi cukup besar yang menyebabkan Tulungagung kembali menjadi kedung (rawa). ${ }^{34}$

\footnotetext{
${ }^{32}$ Ngusman, wawancara 22 April 2007..

${ }^{33}$ Suara Masyarakat, 5 Agustus 1955

${ }^{34}$ Pewarta Surabaya, 4 Maret 1957
} 
Dinas Pengairan Provinsi Jawa Timur mendapat tanggung jawab terkait dengan adanya rencana rehabilitasi Terowongan Neyama yang dijuluki sebagai "Parit Raya". Parit diartikan sebagai air yang mengalir dari Kali Ngasinan, Kali Tawing, dan kali kecil lainnya yang berada di sebelah barat Kali Ngrowo dialirkan ke bagian hulu Kali Ngrowo yang kemudian langsung dibuang ke Samudera Indonesia melalui Terowongan Neyama. ${ }^{35}$ Proyek perbaikan Terowongan Neyama tersebut sudah terealisasi sejak bulan Oktober 1959. Bangunan terowongan dimulai dari PT Kashima Kensetsu yang dibimbing oleh PT Nihon Koei. Selain adanya upaya proyek pengentasan banjir dengan rehabilitasi Terowongan Neyama juga terdapat adanya upaya dari Tentara Nasional Indonesia Angkatan Darat yang berusaha membangun Jembatan Ngujang yang bersifat sementara atau yang sering disebut sebagai Jembatan Bailey yang dijadikan sebagai pengganti perahu tambang. ${ }^{36}$

Upaya pemerintah pusat dalam penyediaan bangunan Kali Konto di Blitar tujuannya untuk memperlambat gerakan pasir yang belum terealisasikan sehingga banjir datang kembali. Ketidakpastian pemerintah pusat didasari atas keadaaan ekonomi yang belum stabil sehingga mengakibatkan banjir di daerah Blitar, Tulungagung, Kediri, Nganjuk, Jombang, Mojokerto, dan Sidoarjo. Dalam laporan dari media, banjir muncul kembali dikarenakan adanya sedimentasi pasir letusan Gunung Kelud yang semakin tinggi ${ }^{37} \mathrm{Hal}$ itulah yang menyebabkan rakyat resah.

Pada tanggal 2 Oktober 1960, Menteri Pengerahan Tenaga Rakyat (PETERA) Sudibjo y mengatakan bahwa akar masalah dari banjir adalah tingginya permukaan dasar sungai yang mencapai 3 - 5 meter sehingga menyebabkan luapan air ke daratan. Oleh karena itu, perlu adanya pengerukan pasir yang tujuannya untuk mengurangi kepadatan karya dikalangan rakyat karena ini tidak semata-mata tugas pemerintah saja melainkan juga tugas rakyat. Rakyat harus ikut serta membantu dan andil dalam menyukseskan proyek yang dibangun oleh pemerintah. Pemerintah menyelenggarakan proyek yang dimulai dari hilir Brantas dengan cara menggali permukaan menjadi lebih dalam. ${ }^{38}$

35 Nurcholis. 2004. Sejarah Terowongan Neyama: Sebuah Tragedi Kerja Rodi. Tulungagung: Kasubdin Sejarah dan Kepurbakalaan, Dinas Pariwisata dan Kebudayaan Kabupaten Tulungagung.

${ }^{36}$ Kompas, 22 April 1977

${ }^{37}$ Pewarta Surabaya, 4 Maret 1957.

${ }^{38}$ Terompet Masyarakat, 3 Oktober 1960 
Pembangunan Terowongan Neyama yang dilakukan oleh PT Kashima Kensetsu berhasil selesai bulan oktober 1961 dengan memperlebar diameter terowongan menjadi 7 meter dan panjangnya 950 meter. Pasca rehabilitasi terowongan Neyama dan proyek pengerukan pasir di hilir Brantas sangat berdampak besar yang dibuktikan adanya genangan banjir yang mulanya besar sekarang semakin mengecil. Selain itu di daerah Rawa Bening dan Rawa Gesikan mengalami penyusutan debit air. Hal itulah yang menimbulkan adanya pengubahan nama Terowongan Neyama menjadi Terowongan Tulungagung Selatan. ${ }^{39}$

\section{Tabel 1}

Genangan air akibat banjir pasca dilakukan rehabilitasi

Terowongan Neyama

\begin{tabular}{|c|c|}
\hline Tahun & Luas lahan terkena banjir \\
\hline 1964 & $20.660 \mathrm{Ha}$ \\
1965 & Tidak ada genangan \\
1966 & $5.500 \mathrm{Ha}$ \\
1967 & $4.850 \mathrm{Ha}$ \\
1968 & $10.000 \mathrm{Ha}$ \\
1969 & Tdk ada Genangan \\
\hline
\end{tabular}

Sumber: Laporan Perencanaan Proyek Brantas

Genangan air setidaknya telah berkurang meskipun setiap tahun daerah tersebut masih terkena banjir. Pada tahun 1968 daerah Tulungagung mengalami banjir yang lebih besar dari banjir tahun sebelumnya. Banjir diakibatkan karena adanya banjir kiriman dari daerah hulu Sungai Brantas. Banjir tersebut berada di wilayah Karangkates sehingga menyebabkan pembangunan Bendungan Karangkates terganggu. ${ }^{40}$ Akibat banjir kiriman ini wilayah tengah

39 Latif Kusairi, 2007. "Historiografi Indonesiasentris dan Memory: Studi Penyebutan Terowongan Niyama Tulungagung" (Makalah diterbitkan dalam rangka Seminar Nasional XII Ikatan Himpunan Mahasiswa Sejarah se-Indonesia (IKAHIMSI) dengan tema Pemikiran Ulang Historiografi dan Sistem. Universitas Negeri Semarang.

${ }^{40}$ Arsip Kota Surabaya no. 1277. Laporan Singkat Peninjauan Banjir ke daerah Karangkates, Tumpang, dan Kedungkandang. Surabaya. 
Sungai Brantas seperti Tulungagung terjadi banjir. Hal itulah yang diakibatkan karena banjir kiriman dan curah hujan yang tinggi di wilayah Tulungagung.

\section{Banjir Tahun 1971 Awal Perencanaan Pemerintah}

Setelah sempat mengecil daerah genangan banjir akibat dari pembukaan kembali Terowongan Neyama, tahun 1971 terjadi banjir besar. Banjir yang terjadi kali ini selain diakibatkan adanya pendangkalan dasar sungai juga diakibatkan adanya kondisi terowongan yang kembali tidak beroperasi penuh yang mengakibatkan endapan pada terowongan. Terowongan yang direhabilitas pada tahun 1956 hanya bersifat sementara. Banjir yang terjadi bulan 10 Februari 1971 ini mempunyai debit yang hampir sama pada banjir tahun 1955. Akibatnya banjir ini pula banyak warga yang mengungsi ke daerah yang lebih tinggi dikarenakan adanya genangan yang cukup lama.

\section{Gambar 2}

Daerah Genangan Banjir di Tulungagung tahun 1971

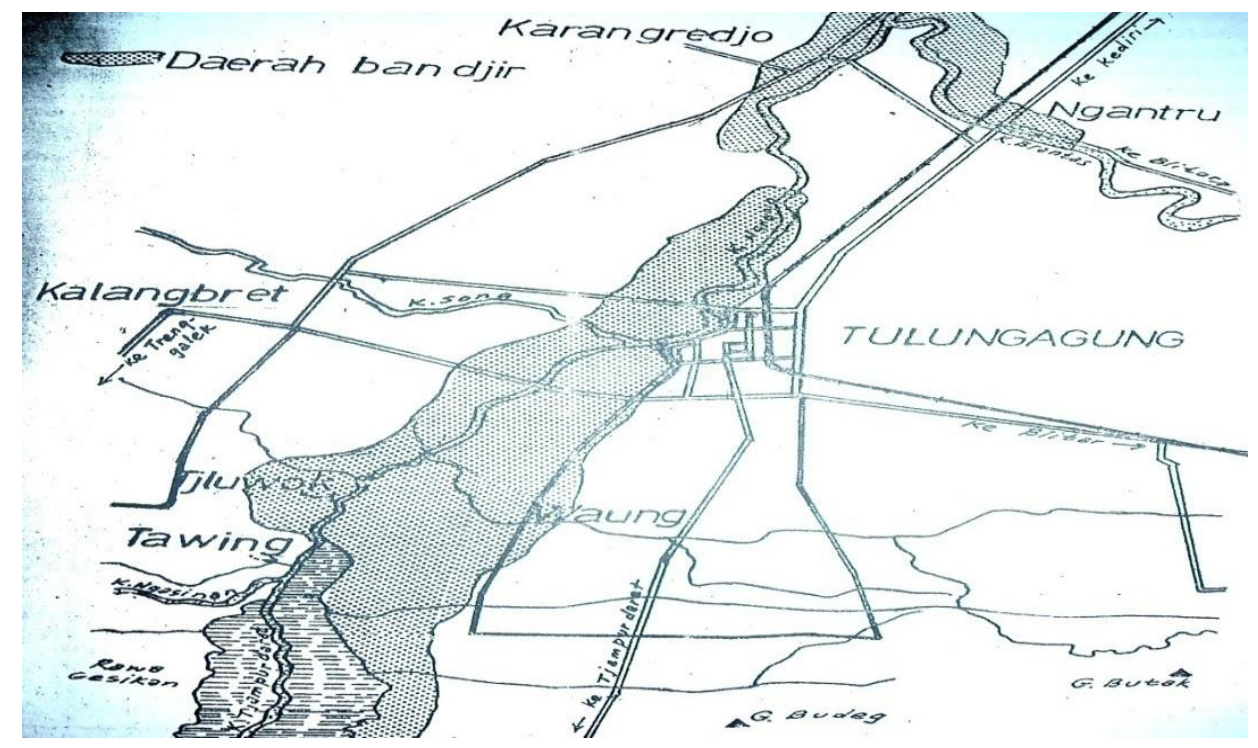

Sumber : Arsip Daerah Jawa Timur no 75/LAP/PPB

Asisten Perencanaan Staf Proyek Brantas mengadakan peninjauan ke daerah banjir Sungai Brantas. Ia menyebutkan bahwa perlunya proyek rehabilitasi baru dan penanggulangan yang terpadu agar banjir yang terjadi di Sekitar Brantas bisa teratasi. Dalam peninjauan tersebut mereka menyimpulkan bahwa banjir yang terjadi masih mempunyai penyebab yang relatif sama dengan banjir terdahulu. Banjir terjadi karena naiknya dasar Sungai Brantas oleh endapan pasir 
akibat meletusnya Gunung Kelud yang tertimbun sepanjang palung sungai dari Kali Lekso di Blitar hingga di muaranya Kali Porong, karena naiknya dasar tersebut maka terjadi pendangkalan dari palung sungai yang menyebabkan menurunya kapasitas mengalirkan air. ${ }^{41}$ Permukaan air yang semakin naik di Sungai Brantas menyebabkan daerah yang berada di dataran rendah seperti Blitar, Tulungagung, Kediri, dan Nganjuk terjadi pembendungan terhadap sungai yang bermuara ke Sungai Brantas, seperti Kali Ngrowo di Tulungagung, Kali Kedungsoko di Nganjuk, dan Kali Kedak di Kediri. Banjir di Tulungagung ini menyebabkan sepanjang daerah aliran Kali Ngrowo sejak dari Muara hingga di Rawa Gesikan (Rawa Campurdarat) mengalami genangan. Namun, genangan ini hanya bersifat sementara dan terjadi rutin setiap tahun. ${ }^{42}$

Dari catatan debit banjir yang dihimpun oleh pos pengamatan di beberapa lokasi banjir bulan Januari 1971 mempunyai kapasitas air seperti Pos Kaulon di Blitar, Pos Djeli di perbatasan Tulungagung - Kediri, dan Pos Pakuntjen di Muara Kali Ngrowo ke Brantas. Pencatatan tersebut dilakukan dengan melihat adanya kecepatan air yang ada pasca naiknya endapan pasir di Sungai Brantas, sehingga bisa untuk referensi pembuatan bendungan penahan aliran air dan kadar pasir.

\section{Tabel 2}

Debit banjir yang terjadi di beberapa Pos Pengamatan di Sungai Brantas bulan Januari 1971

\begin{tabular}{|c|l|l|l|}
\hline Tanggal & \multicolumn{1}{|c|}{ Pos Kaulon } & \multicolumn{1}{|c|}{ Pos Djeli } & Pos Pakuntjen \\
\hline 10 & $195,981 \mathrm{M}^{3} /$ detik & $313,352 \mathrm{M}^{3} /$ detik & $40,332 \mathrm{M}^{3} /$ detik \\
11 & $187,680 \mathrm{M}^{3} /$ detik & $230,114 \mathrm{M}^{3} /$ detik & $39,163 \mathrm{M}^{3} /$ detik \\
12 & $169,114 \mathrm{M}^{3} /$ detik & $182,231 \mathrm{M}^{3} /$ detik & $33,419 \mathrm{M}^{3} /$ detik \\
13 & $195,981 \mathrm{M}^{3} /$ detik & $365,583 \mathrm{M}^{3} /$ detik & $37,120 \mathrm{M}^{3} /$ detik \\
14 & $217,721 \mathrm{M}^{3} /$ detik & Tdk ada pencatatan & Tdk ada pencatatan \\
15 & $322,568 \mathrm{M}^{3} /$ detik & $547,095 \mathrm{M}^{3} /$ detik & $72,892 \mathrm{M}^{3} /$ detik \\
16 & $376,602 \mathrm{M}^{3} /$ detik & $668,782 \mathrm{M}^{3} /$ detik & $59,689 \mathrm{M}^{3} /$ detik \\
17 & $189,630 \mathrm{M}^{3} /$ detik & $305,782 \mathrm{M}^{3} /$ detik & $69,153 \mathrm{M}^{3} /$ detik \\
18 & $205,971 \mathrm{M}^{3} /$ detik & $259,210 \mathrm{M}^{3} /$ detik & $60,214 \mathrm{M}^{3} /$ detik \\
\hline
\end{tabular}

Sumber: Dinas Pengairan Seksi Tulungagung tahun 1971.

\footnotetext{
${ }^{41}$ Arsip Derah Jawa Timur, No 75/ LAP/PPB

${ }^{42}$ Mujiran, wawancara 23 Desember 2008
} 
Pencatatan banjir yang terjadi di daerah Brantas ini bersamaan dengan terjadinya banjir di Kali Ngrowo. Akibatnya daerah yang berada di hulu sampai Hilir Kali Ngrowo mengalami banjir. Dinas Pengairan Seksi Tulungagung yang melakukan pengamatan dan pencatatan terhadap besarnya banjir menyimpulkan bahwa yang menyebabkan banjir akibat.

1. Meningginya dasar Sungai Brantas sehingga menyebabkan hambatan aliran kali Ngrowo.

2. Ketidaklancaran aliran air Kali Ngrowo dan derasnya aliran Sungai Brantas serta adanya kali-kali kecil yang bermuara ke Kali Ngrowo menyebabkan adanya kadar Pasir (silt) yang tinggi dan mengendap di dasar sungai sehingga lambat laun terjadi pendangkalan pada palung sungai (river channel) dari Kali Ngrowo.

3. Kondisi Parit Raya berfungsi sebagai pembelokkan aliran air dari Kali Ngasinan Trenggalek menuju ke Terowongan Neyama belum bisa beroperasi penuh akibat yang menurut rencana berkapasitas $350 \mathrm{M}^{3 /}$ detik, karena beum sempurnanya pengalian parit hanya dapat mengalirkan $150 \mathrm{M}^{3} / \mathrm{detik}-250 \mathrm{~m}^{3} /$ detik. $^{43}$

Maka dari itu dalam cacatan Dinas Seksi Pengairan Tulungagung perlu adanya tidakan yang lebih tepat dalam mengatasai banjir di Tulungagung ini. Tindakan yang perlu diambil yaitu tindakan jangka pendek dan jangka panjang. Jangka pendek yaitu dengan menyempurnakan Parit Raya hingga mencapai kapasitas yang direncanakan $350 \mathrm{M}^{3} /$ detik sedangkan tindakan jangka penjang dengan mengadakan improvement lebih lanjut dengan melakukan pembuatan waduk di daerah Kali Ngasinan dan Kali Ngrowo, peninggian tanggul di Kali Ngrowo dan Sungai Brantas, pembuatan pintu di Kali Ngrowo, Rawa Gesikan, dan Rawa Penik, dan perlu perbaikan watershed management daerah pengaliran Kali Ngrowo dan Kali Ngasinan. ${ }^{44}$

Dalam laporan banjir yang terjadi di Tulungagung, pihak pemerintah membentuk Tim Pengendalian Proyek Brantas dengan bekerja sama dengan pihak Dinas Seksi Pengairan Tulungagung. Kendala dari proyek tersebut adalah ketidak adanya dana keuangan yang masuk

\footnotetext{
${ }^{43}$ Arsip Daerah Jawa Timur no 75/LAP/PPB dalam Laporan Dinas Seksi Pengairan Tulungagung ${ }^{44}$ Ibid
} 
sehingga mengalami berbagai kendala. Pemerintah mengajak masyarakat untuk bersedia melakukan pengerukan di daerah Kali Ngrowo atau lebih disebut proyek Parit Agung. ${ }^{45}$

\section{PENUTUP}

Keberadaan sungai yang melimpah sering menyebabkan banjir. Bencana banjir diakibatkan oleh beberapa faktor di antaranya adalah meluapnya Sungai Brantas, meletusnya Gunung Kelud, iklim cuaca, dan curah hujan yang tinggi, ketidak lancaran aliran air Kali Ngrowo dan derasnya aliran Sungai Brantas, dan Parit Raya. Dalam penanganan banjir pasca kemerdekaan dilakukan dengan cara membuat Terowongan Neyama, pembuatan bendungan penahan perbaikan terowongan, penampungan pasir di Gunung Kelud, menyempurnakan parit raya, dan mengadakan imporevent terkait pembuatan waduk Kali Ngasinan dan Kali Ngrowo, meninggikan tanggul di Sungai Brantas, pembuatan pintu Kali Ngrowo dan Gesikan, dan perlu perbaikan daerah pengaliran Kali Ngrowo dan Kali Ngasinan.

${ }^{45}$ ibid 


\section{DAFTAR PUSTAKA}

Aptianto, T. C. (2005). Kota dan Kapitalisme Perkebunan: Jember dalam perubahan Zaman 1900-1970. Yogyakarta: Ombak.

Ariefana, P., \& Aranditio, S. (2019). Banjir Yogyakarta - Jateng, 2 Tewas, 7.240 Orang Mengungsi. Suara.Com.

Arif, S. (2019). Hujan Deras, Banjir Serentak Landa Tulungagung, Blitar, dan Trenggalek. Sindonews.Com.

Arsip Daerah Jawa Timur, no 124/6K/PPB. Kadipaten Ngrowo merupakan wilayah Tulungagung sebelum nantinya pada tahun 1901 berubah menjadi Kabupaten Tulungagung. (n.d.).

Arsip Daerah Jawa Timur no 75/LAP/PPB., dalam Laporan Dinas Seksi Pengairan Tulungagung. (n.d.).

Arsip Derah Jawa Timur, No 75/ LAP/PPB. (n.d.).

Arsip, K. S. (n.d.). Laporan Singkat Peninjauan Banjir ke aderah Karangkates, Tumpang, dan Kedungkandang. Surabaya.

Daldjoeni. (1984). Geografi Kesejarahan Indonesia I. Bandung: Alumni.

Daniati, R. P., \& Sariffudin. (2015). Tingkat Kerentanan Masyarakat Terhadap Bencana Banjir di PerumnaasTlagasari Kota Semarang. Jurnal Pengembangan, 3(2).

Daud, A. (2019). BNPB: 477 Bencana Alam Terjadi Sejak Januari 2019. Katadata.Co.Id.

Gostlack, L. (1982). Mengerti Sejarah. Jakarta: Universitas Indonesia Press.

Harian Umum, 17 Desember 1954.

Heijboer, P. (1998). Agresi Militer Belanda: Mempertahankan Pending Zamrud Sepanjang Khatulistiwa 1945 - 19449. Jakarta: Grafindo.

Isteni, N. (2018). Banjir di Tulungagung Tahun 1955 - 1986. Jurnal Avatar, 6(2), 36-45.

Jatmiko, A. (2019, April). Korban Banjir Jakarta, Sebanyak 2.942 Warga Harus Mengungsi. 


\section{Katadata.Co.Id.}

Karasawa, A. (1993). Mobilisasi dan Kontrol: Studi Tentang Perubahan Sosial di Pedesaan Jawa 1942-1945. Jakarta: Grafindo.

Kompas, 22 April 1977.

Kusairi, L. (2007). Historiografi Indonesiasentris dan Memory: Studi Penyebutan Terowongan Niyama Tulungagung (Makalah diterbitkan dalam rangka Seminar Nasional XII Ikatan Himpunan Mahasiswa Sejarah se-Indonesia (IKAHIMSI) dengan tema Pemikiran Ulang Historiografi dan Sistem. Universitas Negeri Semarang.

Meleong, L. J. (2010). Metodologi Penelitian Kualitatif. Bandung: Remaja Rosdakarya.

Newman, L. (2000). Social Research Methods Qualitative dan Quantitative. Approaches: Boston: Allyn and Bacon.

Nugroho, A. (2015). Analisis Faktor Lingkungan dalam Kejadian Leptospirosis di Kabupaten Tulungagung. Jurnal Balaba, 11(2), 73-80.

Nurcholis. (2004). Sejarah Terowongan Neyama: Sebuah Tragedi Kerja Rodi. Tulungagung: Kasubdin Sejarah dan Kepurbakalaan, Dinas Pariwisata dan Kebudayaan Kabupaten Tulungagung.

Penulis, T. (2004). Sejarah dan Babad Tulungagung edisi Revisi. Tulungagung: Pemkab Tulungagung.

Pewarta Surabaya, 4 Maret 1952.

Pewarta Surabaya, 21 Maret 1952.

Said, S. (2019). Madiun Dilanda Banjir Hebat, 515 Orang Dievakuasi. Sindonews.Com.

Sang, S. (2013). Sejarah Tulungagung. Kompasiana.Com.

Suara Masyarakat, 21 Juli 1955.

Suara Masyarakat, 26 Juli 1955. 
Suara Masyarakat, 1 Agustus 1955.

Suara Masyarakat, 2 Agustus 1955.

Suara Masyarakat, 3 Agustus 1955.

Suara Masyarakat, 4 Agustus 1955.

Suara Masyarakat, 5 Agustus 1955.

Sugiyono. (2018). Metode Penelitian Pendidikan: Pendekatan Kualitatif, Pendekatan Kuantitatif, dan $R \& D$. Bandung: Alfabeta.

Sumarkanto. (2002). Pencemaran Lingkungan Perairan Sungai Salah Satu Faktor Penyebab Banjir di Jakarta. Jurnal Teknologi Lingkungan, 3(1), 13.

Surabaya, P. (1957). No Title. Pewarta Surabaya.

Surya, 3 Oktober 2007.

Terompet Masyarakat, 3 Oktober 1960.

www.tulungagung.go.id. Dalam Sejarah Kabupaten Tulungagung. Diakses 03 September 2008.

Yusuf, Y. (2005). Anantomi Banjir Kota Pantai: Perspektif Geografi. Surakarta: Pustaka Cakra.

Kadit, wawancara 12 Juni 2008

Ngusman, wawancara 22 April 2007.

Mujiran, wawancara 23 Desember 2008. 